\title{
UVODNIK
}

\section{NOVA NEVOJAŠKA TVEGANJA}

Beseda tveganje je v spletni izdaji Slovarja slovenskega knjižnega jezika iz leta 2000 pojasnjena kot glagolnik besede tvegati. Kolikor lahko laično razumemo, gre za sinonim besede nevarnost, ki je pojasnjena kot možnost nesreče, škode ali kot nekaj slabega, neprijetnega sploh. V slovarju je navedena še možnost uporabe besede riziko. V izbranem naslovu smo imeli v mislih tveganja, nevarnosti in riziko, ki niso vojaškega izvora, hkrati pa so še novi. O virih ogrožanja, tveganjih in nevarnostih najdemo podroben opis v Resoluciji o strategiji nacionalne varnosti iz leta 2010. V četrtem poglavju je zapisano, da se viri ogrožanja in tveganja za nacionalno varnost Republike Slovenije z vidika porekla pojavljajo na globalni, nadnacionalni in nacionalni ravni. Globalni viri ogrožanja in tveganja so podnebne spremembe, globalna finančna, gospodarska ter socialna tveganja in krizna žarišča. Nadnacionalni viri ogrožanja in tveganja so terorizem, nedovoljene dejavnosti na področju konvencionalnega orožja, orožja za množično uničevanje in jedrske tehnologije, organiziran kriminal, nezakonite migracije, kibernetske grožnje, zloraba informacijskih tehnologij in sistemov ter dejavnost tujih obveščevalnih služb. Med nacionalne vire ogrožanja in tveganja spadajo ogrožanje javne varnosti, naravne in druge nesreče, omejenost naravnih virov, degradacija življenjskega okolja, zdravstveno-epidemiološke grožnje ter negotovosti, med katere resolucija uvršča revščino, negativna demografska gibanja, izpostavljenost kritične infrastrukture itn. Toliko o virih ogrožanja in tveganjih za nacionalno varnost. Ali lahko govorimo, da gre za nova nevojaška tveganja? Težko. Nekatera so novejša, vendar niso povsem nova, spet druge oblike so se že pojavljale $\mathrm{v}$ daljni ali bližnji preteklosti in se morda zelo kmalu pojavijo $\mathrm{v}$ še novejši obliki. Ali pa tudi ne, kar pa ne pomeni, da avtorji v tej številki niso posredovali zanimivih vidikov morebitnih tveganj, varnosti ali rizika. Prepričajte se sami.

Branimir Furlan je v prejšnji številki obljubil nadaljevanje svojega članka. Tako v nadaljevanju v tej številki z enakim naslovom Neučinkovitost vojske kot pokazatelj neustreznosti civilnega nadzora (2) pravi, da je v prvem delu predstavil 
teoretično-metodološki okvir analize, v drugem delu pa predstavlja rezultate raziskave o stanju civilno-vojaških odnosov v Republiki Sloveniji ter o vplivih civilnega nadzora na učinkovitost Slovenske vojske. Kakšni so torej ti rezultati in kakšna je učinkovitost vojske po avtorjevih ugotovitvah?

Z metodologijo ugotavljanja voditeljskega potenciala končno do odličnih vojaških voditeljev? je naslov članka Dejana Okoviča. Pravi, da bodo imeli v Slovenski vojski po uvedbi metodologije za ugotavljanje voditeljskega potenciala na voljo vsa orodja za uvajanje vojaškega voditeljstva. Navaja, da je socialna moč tisto, kar daje voditelju sposobnost, da vodi svoje sledilce, ti pa so eden izmed pogojev za obstoj voditeljstva. Odgovori na vprašanja, za kakšna orodja gre in kako ugotavljati voditeljski potencial ter kaj sploh voditeljstvo je, se bralcem obetajo v članku.

Arktika je podvržena podnebnim spremembam, ki odkrivajo njen energetski, politični in gospodarski potencial ter jo spreminjajo v novi »orient«, pravi Sandra Martinič v članku z naslovom Energetska tekma za Arktiko. Avtorica pojasni, kaj Arktika sploh je - morje ali kopno, kakšni so njeni energetski potenciali, koga vse zanimajo in kako bi do njih lahko prišli. Ko bo dostop do energetskih virov urejen tudi s formalnopravnega mednarodnega vidika, bo najverjetneje prišlo do večje militarizacije območja, saj bo varnost virov in okolja zelo pomembna.

Potopitev avstro-ogrske admiralske ladje Viribus Unitis skozi italijansko arhivsko vojaško dokumentacijo je naslov članka, ki ga je pripravil Matjaž Bizjak. V njem avtor zelo podrobno popelje bralca skozi arhivsko gradivo v davno leto 1918. Bolj natančno, 1. novembra tega leta sta dva italijanska diverzanta zelo izvirno uspela potopiti avstro-ogrsko admiralsko ladjo v Pulju. Njuna zamisel je bila res posebna, izvedba pa izjemna. Tik pred eksplozijo sta bila sicer zelo presenečena nad trenutnim stanjem, a ura na bombi je že odštevala in časa za improvizacijo je zmanjkovalo.

Anton Kanduti je napisal članek z naslovom Pilotski projekt: vojašnični klubi $v$ Slovenski vojski in pot naprej. Pravi, da sta v Slovenski vojski dva vojašnična kluba, in sicer v Kadetnici v Mariboru in v Vojašnici Jerneja Molana v Cerkljah ob Krki. Kako delujeta, kakšne so pravne podlage za njun obstoj, čemu sta namenjena in kakšne cilje dosegata, vse to in rezultate ankete med zaposlenimi v Slovenski vojski o tej temi predstavlja v članku.

Vabljeni k branju in sodelovanju! 